\title{
Observed relationships of ozone air pollution with temperature and emissions
}

\author{
Bryan J. Bloomer, ${ }^{1,2}$ Jeffrey W. Stehr, ${ }^{2}$ Charles A. Piety, ${ }^{2}$ Ross J. Salawitch, ${ }^{2}$ \\ and Russell R. Dickerson ${ }^{2}$ \\ Received 14 January 2009; revised 11 March 2009; accepted 27 March 2009; published 5 May 2009.
}

[1] Higher temperatures caused by increasing greenhouse gas concentrations are predicted to exacerbate photochemical smog if precursor emissions remain constant. We perform a statistical analysis of 21 years of ozone and temperature observations across the rural eastern U.S. The climate penalty factor is defined as the slope of the ozone/temperature relationship. For two precursor emission regimes, before and after 2002, the climate penalty factor was consistent across the distribution of ozone observations. Prior to 2002, ozone increased by an average of $\sim 3.2 \mathrm{ppbv} /{ }^{\circ} \mathrm{C}$. After 2002, power plant $\mathrm{NO}_{\mathrm{x}}$ emissions were reduced by $43 \%$, ozone levels fell $\sim 10 \%$, and the climate penalty factor dropped to $\sim 2.2 \mathrm{ppbv} /{ }^{\circ} \mathrm{C}$. $\mathrm{NO}_{\mathrm{x}}$ controls are effective for reducing photochemical smog and might lessen the severity of projected climate change penalties. Air quality models should be evaluated against these observations, and the climate penalty factor metric may be useful for evaluating the response of ozone to climate change. Citation: Bloomer, B. J., J. W. Stehr, C. A. Piety, R. J. Salawitch, and R. R. Dickerson (2009), Observed relationships of ozone air pollution with temperature and emissions, Geophys. Res. Lett., 36, L09803, doi:10.1029/2009GL037308.

\section{Introduction}

[2] Power plant $\mathrm{NO}_{\mathrm{x}}$ emissions decreased by $43 \%$ for the time period 1995 to 2002 compared with 2003 to 2006 as a result of air pollution control programs in the eastern United States [Kim et al., 2006; Bloomer, 2008.] Emissions from automobiles and industrial activity have essentially remained constant, as indicated from satellite observations of tropospheric $\mathrm{NO}_{2}$ [Kim et al., 2006]. Early indications from ambient monitoring networks and atmospheric chemical transport models provide evidence that ozone amounts have declined as a result of fallen power plant emission [Gégo et al., 2007, 2008].

[3] Temperature can be used as a surrogate for the meteorological factors influencing surface ozone formation [Jacob et al., 1993; Ryan et al., 1998; Camalier et al., 2007]. Temperature has been rising, on average, in the eastern U.S. [Intergovernmental Panel on Climate Change (IPCC), 2007]. Surface ozone is expected to rise, all else being equal, with an increase in temperature [Environmental Protection Agency, 2006]. The ozone temperature relation-

\footnotetext{
${ }^{1}$ U.S. Environmental Protection Agency, Washington, D. C., USA.

${ }^{2}$ Department of Atmospheric and Oceanic Science, University of Maryland, College Park, Maryland, USA.
}

Copyright 2009 by the American Geophysical Union. 0094-8276/09/2009GL037308\$05.00 ship has been investigated in the past [Sillman and Samson, 1995; Sillman, 1999]. However, questions remain regarding how this relationship changes over time, by location, and with precursor emissions.

[4] Modeling studies suggest a penalty in ozone air quality resulting from forecast climate changes. Wu et al. [2008] forecast a penalty of 2 to 5 ppbv in daily maximum 8-hour averaged surface ozone amounts in parts of the eastern U.S., offsetting expected air quality improvement from emission reductions, between 2000 and 2050. Jacob and Winner [2009] provide a review of recent modeling of air quality changes under various scenarios of forecasted global climate change and indicate a climate change penalty from 1 to 8 ppbv ozone is likely in the eastern U.S. this century.

[5] Air quality models need evaluation using observations to assess model performance and to establish confidence in the effect of climate change on surface ozone. Areas with rising temperatures and precursor emissions are projected to suffer the consequences of worsening air pollution including increases in mortality and morbidity [Bell et al., 2005; National Research Council (NRC), 2008] along with significant damage to crops [Ellingsen et al., 2008].

[6] Here we investigate observational data obtained in the rural eastern U.S. over the last 21 years. Specifically, we examine hourly ozone and temperature relationships measured by the CASTNET network. We group the data into four chemically coherent receptor regions (Figure 1a). We investigate the ozone vs. temperature relationship for each receptor region, for two time periods characterized by differing power-plant emissions: before and including 2002 and after 2002. The analysis shows a consistent ozone temperature relationship across the eastern U.S. and that the slope of the relationship decreases after the power-plant emissions reductions.

\section{Measurements and Statistical Method}

\section{1. $\mathrm{NO}_{\mathrm{x}}$ Emissions}

[7] $\mathrm{NO}_{\mathrm{x}}$ emissions from power plants were historically estimated from fuel sampling and analysis methods. Since 1995, continuous emission monitoring equipment has been operating in the exhaust gas stream of the largest fossil fuel fired plants nationwide. Care must be used in assessing $\mathrm{NO}_{\mathrm{x}}$ emission from power plants when combining data sources and when using emissions numbers from government databases. We have analyzed the historical trend of ozone season (1 May to 30 September) $\mathrm{NO}_{\mathrm{x}}$ emission from power plants and conclude two distinct emission regimes can be constructed [see also Bloomer, 2008]. 


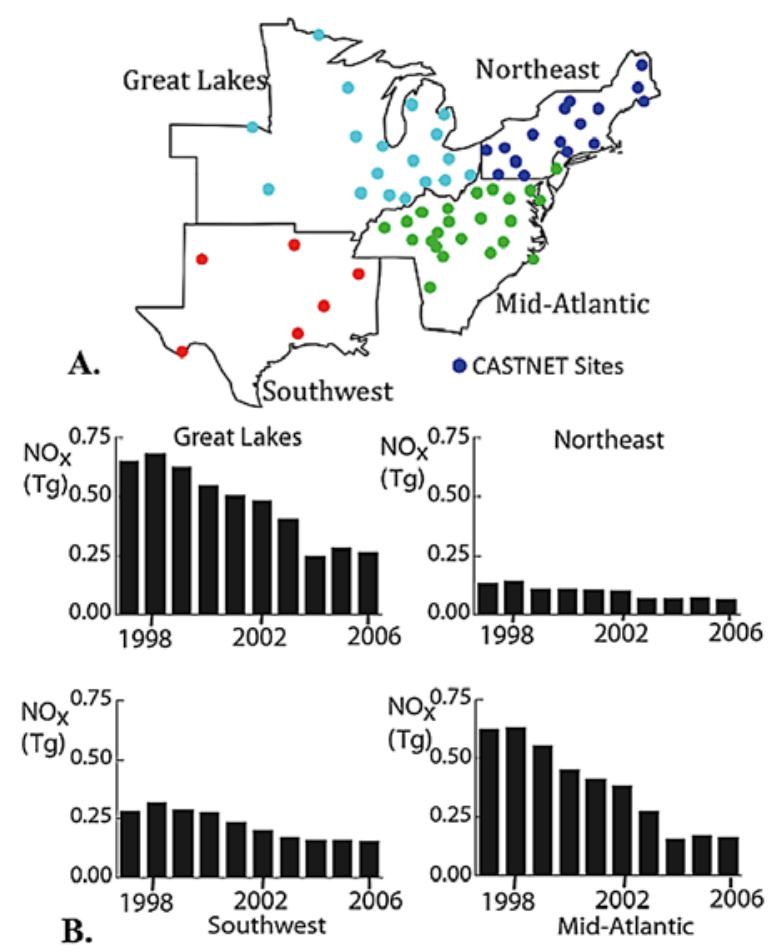

Figure 1. (a) Grouping of States and CASTNET sites based on Lehman et al. [2004] representing chemically coherent receptor regions for ozone air pollution. (b) Power plant ozone season (May to September) $\mathrm{NO}_{\mathrm{x}}$ emissions (as $\mathrm{Tg} \mathrm{NO}_{2}$ where $1 \mathrm{Tg} \mathrm{NO}_{2}$ is equivalent to $0.304 \mathrm{Tg} \mathrm{N}$ ) aggregated by region and year.

[8] Power plant $\mathrm{NO}_{\mathrm{x}}$ emissions (Figure 1b) decreased as a result of air pollution control programs in the eastern United States by $43 \%$, on average, around 2002. Emissions from automobiles and industrial activity have essentially remained constant [Kim et al., 2006]. Using the power plant emission changes to define two distinct emission regimes, we assign the period prior to and including 2002 to one regime and the period after the $43 \%$ reduction to a post 2002 emission regime.

\subsection{Surface Ozone and Temperature Observations}

[9] Co-located, rural observations of ozone concentration and temperature are collected by the Clean Air Status and Trends Network (CASTNET), operated by the U.S. EPA since $1987 \mathrm{http}: / /$ www.epa.gov/castnet) and described by Clarke et al. [1997]. All ozone and temperature data presented here are simultaneous, hourly averages from the ozone season; only data labeled valid by the CASTNET team were accepted. Temperature is observed with platinum wire resistance thermometers or thermistors and ozone amounts are measured using a UV absorbance method. Observations analyzed here span the ozone seasons from 1987 until 2007.

\subsection{Statistical Approach}

[10] We aggregate CASTNET sites into four chemically coherent regions after the results of Lehman et al. [2004] (Figure 1a) and the two time periods noted above. This method yields a large number of observations for analysis with over 3 million simultaneously valid observations of temperature and ozone across the eastern U.S. For example, the resulting data set for the Mid-Atlantic region includes $1,196,350$ individual valid observations of concurrent temperature and ozone, with 343,398 observations after 2002, and 852,952 from 1987 up to and including 2002 [Bloomer, 2008].

[11] We used the exploratory data analysis techniques described by Wilks [2006]. In general, parametric tests rely on strict assumptions about the probability distribution of the data, such as assuming the distribution is Gaussian. In our study, we do not make these assumptions because more general and conservative conclusions are possible. The shapes of the full ozone and temperature distributions have little documentation in the literature. Non-parametric methods are more robust and resistant to influence from outliers due to instrument error or anomalous conditions. Further details are given in the auxiliary material. ${ }^{1}$

\section{Results and Discussion}

[12] The hourly ozone concentrations (including nighttime observations) dropped post-2002 by about $10 \%$ in the Mid-Atlantic and Northeast regions across the full distribution (Figure 2). Ozone in the Great Lakes and Southwest regions decreased by larger relative amounts in the upper and lower percentiles. A similar reduction is seen in the subset of observations made during daytime hours. Sampling the daily maxima for 1-hour and 8-hour averages (time periods of interest due to their specification by EPA in the National Ambient Air Quality Standards for ozone) shows large decreases at all locations in the distribution. The largest decreases in ozone occur at the highest concentrations. Ozone in the 95th percentile of the 8-hour average daily maxima in the Mid-Atlantic declined $15.6 \mathrm{ppbv}$ after 2002. This observational evidence supports conclusions previously reported from modeling studies [Gégo et al., 2007, 2008].

[13] The ozone concentration (Figure 2) shows decreases across the entire distribution of observed values, pre- to post-2002, for all regions. Figure 2 shows the amount of ozone at each location statistic of the 5th, 25th, 50th, 75th and 95th percentiles occurring prior to and including 2002 (horizontal placement) as well as the change in ozone for each percentile (vertical extent).

[14] Temperature distributions (Figure 2) show that air warmed across the Great Lakes and Mid-Atlantic regions after 2002. Mid-Atlantic temperatures increased the most, especially over the lower portion of the distribution. The median temperature differences are $0.51{ }^{\circ} \mathrm{C}$ for pre to post2002 and $0.68^{\circ} \mathrm{C}$ pre- 1999 to post-2002. These are consistent with published estimates of 0.25 to $0.30^{\circ} \mathrm{C} /$ decade for observed temperature trends for similarly defined regions of the eastern U.S. [IPCC, 2007]. The Mid-Atlantic region has temperature differences larger than those predicted from a global greenhouse gas forcing alone [IPCC, 2007], indicating a regional source of warming due to factors that may not be represented in current global modeling simulations.

\footnotetext{
${ }^{1}$ Auxiliary materials are available in the HTML. doi:10.1029/ 2009GL037308.
} 


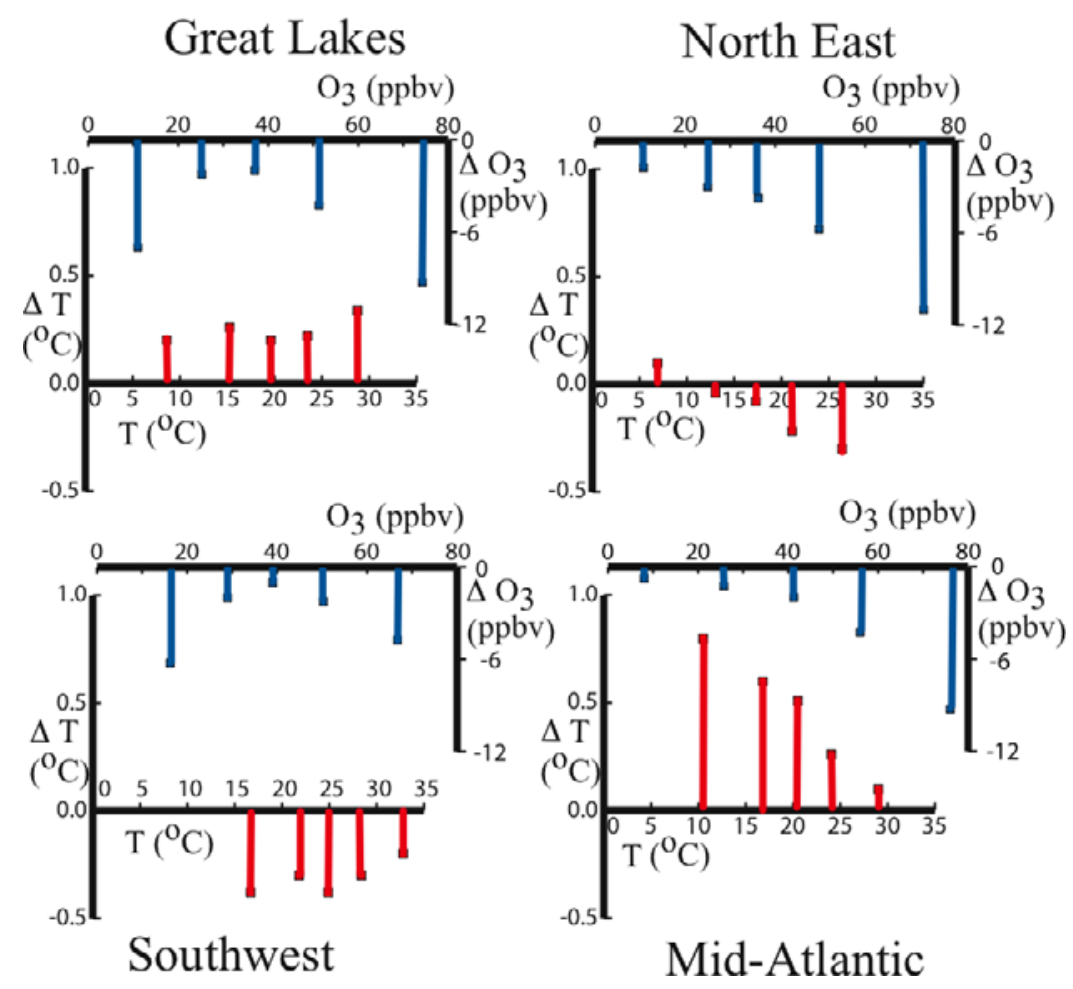

Figure 2. Hourly ozone and temperatures for ozone seasons, aggregated into chemically coherent receptor regions in the eastern U.S. after Lehman et al. [2004] as observed by rural ambient monitoring stations of the CASTNET network. The blue bars at the top of each plot represent the amount of change each location statistic for ozone underwent after 2002. The red bars at the bottom of each plot represent the amount temperature changed, after 2002 compared to the hourly observations obtained between 1987 and 2002. The horizontal position of the bars represents the value of ozone (blue) and temperature (red) for the pre-2002 value of each location statistic, going from left to right in this order: 5th, 25th, 50th, 75th, and 95th percentiles of the full distribution. This graphical representation allows for the reconstruction of the two distributions (pre-2002 and post-2002) for each region for both ozone and temperature. For example, the Mid-Atlantic 5th percentile temperature prior to 2002 was $10^{\circ} \mathrm{C}$, and rose by $0.8^{\circ} \mathrm{C}$ after 2002 ; the 95 th percentile ozone abundance in the Mid-Atlantic was 76 ppbv, and declined by 9 ppbv after 2002.

[15] To investigate further the observational data for a relationship between ozone and temperature, we construct conditional ozone distributions corresponding to specific temperature ranges (Figure 3). For all regions, at all times, in any location within the distribution, ozone concentrations increase with increasing temperatures. The spread in the data as a function of temperature shows how other variables influence ozone at a given temperature. This relationship between the location statistics (e.g., the 50th or 75th percentile values) and temperature reveals a consistently strong dependence of ozone on temperature, regardless of where the distribution is sampled. This approach differs distinctly from filtering the observations by choosing daily maximum 1-hr or 8-hr averages prior to examining the ozone vs. temperature relationship. The strength of the temperature relationship is reinforced by the consistency across the percentiles and the relative insensitivity of the relation to temperature bin size [see also Bloomer, 2008]. Our conclusions are insensitive to the precise choice of year to delineate emission regimes, reflecting the transition period for emission reductions between 1998 and 2002 (see auxiliary material).

[16] The ozone-temperature relationship is linear in all four regions before and after 2002 over the temperature range of 19 to $37^{\circ} \mathrm{C}$. A linear fit of ozone vs. temperature yields nearly the same slope, regardless of which percentile is chosen for the Great Lakes, Northeast, and Mid-Atlantic regions (Figure 3). The average of the slopes of the five linear fits in the Mid-Atlantic region for data collected prior to 2002 , corresponding to the 5 th, 25 th, 50 th, 75 th and 95 th percentiles, is 3.3 ppbv $\mathrm{O}_{3} /{ }^{\circ} \mathrm{C}$, with a minimum of 3.2 and a maximum of $3.5 \mathrm{ppbv} \mathrm{O}_{3} /{ }^{\circ} \mathrm{C}$. The slope decreases to an average of $2.2 \mathrm{ppbv} \mathrm{O}_{3} /{ }^{\circ} \mathrm{C}$ after 2002 , with a similarly small range of 1.9 to $2.6 \mathrm{ppbv} \mathrm{O}_{3} /{ }^{\circ} \mathrm{C}$. The post-2002 data show less ozone compared to the pre-2002 data at the higher temperatures, indicating ozone production became less sensitive to temperature increases after the 2002 emission reductions.

[17] We define the climate penalty factor as the slope of ozone versus temperature. This factor, combined with projections of temperature provides an estimate of how air quality may respond to future warming. Essentially, we are using the variability of the natural system ("today's atmosphere") to quantify the empirical relation between ozone and temperature and are suggesting this relation serves as a starting point for how the future atmosphere will behave. The climate penalty factor is remarkably similar across the Great Lakes, Northeast and Mid-Atlantic regions, with an 


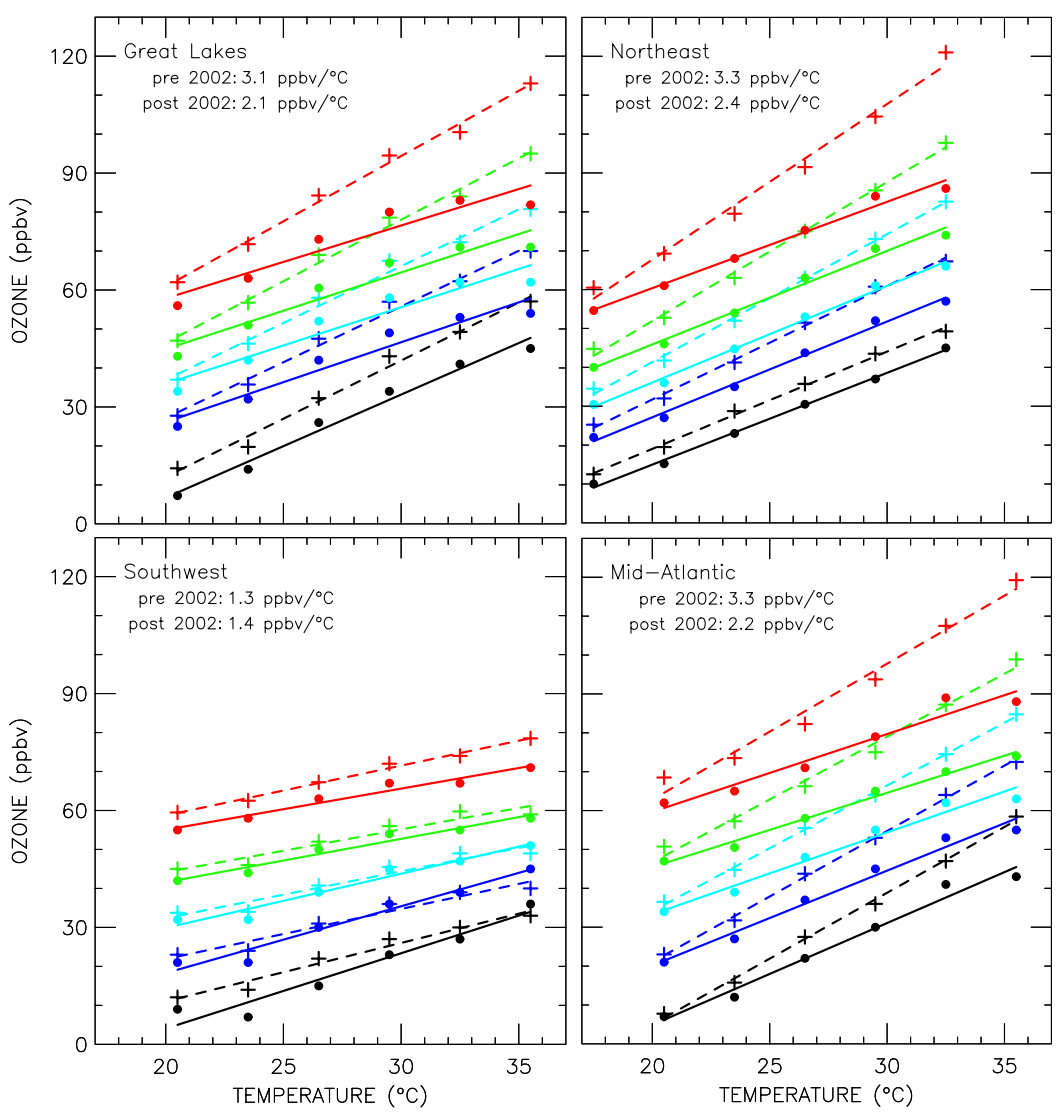

Figure 3. Ozone vs. temperature plotted for $3^{\circ} \mathrm{C}$ temperature bins across the range 19 to $37^{\circ} \mathrm{C}$ for the 5 th, 25 th, 50 th, 75 th and 95th percentiles of the ozone distributions, in each temperature bin, before and after 2002 in chemically coherent receptor regions. Dashed lines and plusses are for the pre-2002 linear fit of ozone as a function of temperature; solid lines and filled circles are for after 2002. Color and position correspond to percentile (on top in red are 95th, next pair down in green is 75 th, light-blue is 50th, dark blue is 25 th, and the bottom pair in black are the 5th percentile values.) Values are plotted at the mid-point temperature of the $3^{\circ} \mathrm{C}$ temperature bin. The average slopes given on each panel indicate the climate penalty factors.

average value for the three regions of $3.2 \mathrm{ppbv} \mathrm{O}_{3} /{ }^{\circ} \mathrm{C}$ (range: 3.0 to $3.6 \mathrm{ppbv} \mathrm{O}_{3} /{ }^{\circ} \mathrm{C}$ ) prior to 2002 and $2.2 \mathrm{ppbv}$ $\mathrm{O}_{3} /{ }^{\circ} \mathrm{C}$ (range: 2.0 to $2.5 \mathrm{ppbv} \mathrm{O}_{3} /{ }^{\circ} \mathrm{C}$ ) after 2002 . If the analysis is restricted to data collected only during the daylight hours of 10:00 am to $7 \mathrm{pm}$ local time, smaller values are obtained for the CPF, because the data are restricted to a narrower range of ozone values. However, the daylight-only data show a decline in CPF after 2002 similar in magnitude to that found when all data are considered. Table S1 of the auxiliary material illustrates the sensitivity of CPF to time of day. Applying the CPF reported here to other geographic regions or future climatic conditions requires theoretical development and/or proper analysis of model calculations. Nonetheless, proper representation of this CPF for contemporary conditions may serve as an important test for models used to project future air quality.

[18] In the Southwest region ozone decreased after 2002, but the climate penalty factor remained nearly the same. Ozone production in the Southwest region differs from the other regions of our study in that petrochemical and vehicular emissions dominate; the air is rich in highly reactive hydrocarbons. Advection from power plants may play a smaller role, but observations are relatively sparse and results are less robust. The Southwest region shows a small increase in the climate penalty factor after 2002, with values going from $1.3 \mathrm{ppbv} /{ }^{\circ} \mathrm{C}$ (range: 1.1 to $1.5 \mathrm{ppbv} /{ }^{\circ} \mathrm{C}$ ) before 2002 to $1.4 \mathrm{ppbv} /{ }^{\circ} \mathrm{C}$ (range: 1.1 to $1.9 \mathrm{ppbv} /{ }^{\circ} \mathrm{C}$ ) after 2002 (Figure 3).

[19] The decrease in ozone concentration and decline in the climate penalty factor observed for the Mid-Atlantic, Great Lakes and Northeast regions after 2002 are statistically significant. Both parametric and non-parametric techniques were applied for determining the significance of the differences in ozone, temperature, and the climate penalty factor as discussed above. Distributions of ozone and temperature were compared to parameterized distributions. The distributions are normal in the middle quartiles, departing significantly from normal at higher ozone values; therefore, we opted to use non-parametric techniques for robust results. Wilcox-Mann-Whitney hypothesis testing was performed, and all differences discussed above are highly significant; the probability of falsely rejecting the null hypothesis of no difference is less than 0.001 .

[20] This level of significance was observed for the vast majority of the data. For example, in the Mid-Atlantic 
region, over 950,000 observations, or more than $80 \%$ of the total data, fall between 15 and $37^{\circ} \mathrm{C}$. The significance of the difference in ozone and the climate penalty factor broke down only for the highest temperatures of greater than $37^{\circ} \mathrm{C}$. These observations represent less than 100 data points, a small fraction of the total. Given the known temporal autocorrelation that exists on the scale of hours to days in the data, we opted to develop additional robust and resistant non-parametric estimates of the standard error for the location statistics, and used these estimates to determine significance as well. We have consistently tended toward overestimating the standard error in our statistical analyses, which provides for great confidence in the statistical significance (meaning differences larger than the combined standard error in this case) of the changes in ozone, temperature, and the climate penalty factor for the Mid-Atlantic, Great Lakes, and Northeast regions. Further details of the statistical significance are given in the auxiliary material.

\section{Concluding Remarks}

[21] Our analysis indicates that the climate change penalty in air quality decreases when ozone precursor emissions are reduced, as suggested by modeling studies [e.g., Wu et al., 2008]. The slope of the ozone temperature relationship, sampled at the various location statistics of the full distribution, was $3.2 \mathrm{ppbv} \mathrm{O}_{3} /{ }^{\circ} \mathrm{C}$ (range: 3.0 to $3.6 \mathrm{ppbv}$ $\mathrm{O}_{3} /{ }^{\circ} \mathrm{C}$ ) prior to 2002 and decreased to 2.2 ppbv $\mathrm{O}_{3} /{ }^{\circ} \mathrm{C}$ (range: 2.0 to $2.5 \mathrm{ppbv} \mathrm{O}_{3} /{ }^{\circ} \mathrm{C}$ ) after 2002, coincident with the $43 \%$ reduction in power plant emission of $\mathrm{NO}_{\mathrm{x}}$. Assuming that $\mathrm{NO}_{\mathrm{x}}$ emissions continue to fall, ground level ozone and the climate penalty factor in the eastern U.S. should continue to improve. In regions of increasing $\mathrm{NO}_{\mathrm{x}}$ emissions, including much of the developing world [Richter et al., 2005], ozone will increase more than expected (based upon emissions alone) if temperatures also rise. Predicted rising temperatures [IPCC, 2007] bode ill for air quality and human health [NRC, 2008; West et al., 2006], unless substantial $\mathrm{NO}_{\mathrm{x}}$ emission reductions are implemented. The climate penalty factor is of significant concern to affected populations and should be evaluated for more regions of the globe. The climate penalty factor can be combined with estimates of future temperature increases to quantify possible impacts of warming on air quality. The climate penalty factor provides a means for assessing the ozone/ temperature relationship of air quality models for present day conditions. Proper representation of this relationship would provide confidence in the accuracy of simulations of the impacts of climate change on future air quality.

[22] Acknowledgments. BJB was supported by the US Environmental Protection Agency. RRD, JWS and CAP were supported by the Maryland Department of the Environment. RJS was supported by the National Aeronautics and Space Administration. The authors thank the US EPA CASTNET. We appreciate helpful discussions with Sherri Hunt, Alan Leinbach, Elizabeth Weatherhead, and Darrell Winner. We thank Loretta Mickley, Daniel Jacob and an anonymous reviewer for their helpful comments. Statements in this publication reflect the authors' professional views and opinions and should not be construed to represent any determination or policy of the US EPA.

\section{References}

Bell, M. L., F. Dominici, and J. M. Samet (2005), Meta-analysis of ozone and mortality, Epidemiology, 16, S35.

Bloomer, B. J. (2008), Air pollution response to changing weather and power plant emissions in the eastern United States, Ph.D. dissertation, Univ. of Md., College Park.

Camalier, L., W. Cox, and P. Dolwick (2007), The effects of meteorology on ozone in urban areas and their use in assessing ozone trends, Atmos. Environ., 41, 7127-7137, doi:10.1016/j.atmosenv.2007.04.061.

Clarke, J. F., E. S. Edgerton, and B. E. Martin (1997), Dry deposition calculations for the clean air status and trends network, Atmos. Environ., $31,3667-3678$

Ellingsen, K., et al. (2008), Global ozone and air quality: A multi-model assessment of risks to human health and crops, Atmos. Chem. Phys. Discuss., 8, 2163-2223.

Environmental Protection Agency (2006), Air quality criteria for ozone and related photochemical oxidants, Rep. EPA/600/R-07/145A, Environ. Prot. Agency, Research Triangle Park, N. C.

Gégo, E., et al. (2007), Observation-based assessment of the impact of nitrogen oxides emissions reductions on ozone air quality over the eastern United States, J. Appl. Meteorol. Climatol., 46, 994-1008, doi:10.1175/ JAM2523.1.

Gégo, E., et al. (2008), Modeling analyses of the effects of changes in nitrogen oxides emissions from the electric power sector on ozone levels in the eastern United States, J. Air Waste Manage. Assoc., 58, 580-588.

Intergovernmental Panel on Climate Change (IPCC) (2007), Climate Change 2007: The Physical Science Basis. Contribution of Working Group I to the Fourth Assessment Report of the Intergovernmental Panel on Climate Change, edited by S. Solomon et al., Cambridge Univ. Press, Cambridge, U. K.

Jacob, D. J., J. A. Logan, G. M. Gardner, R. M. Yevich, C. M. Spivakovsky, S. C. Wofsy, S. Sillman, and M. J. Prather (1993), Factors regulating ozone over the United States and its export to the global atmosphere, J. Geophys. Res., 98, 14,817-14,826.

Jacob, D. J., and D. A. Winner (2009), Effect of climate change on air quality, Atmos. Environ., 43, 51-63.

Kim, S.-W., A. Heckel, S. A. McKeen, G. J. Frost, E.-Y. Hsie, M. K. Trainer, A. Richter, J. P. Burrows, S. E. Peckham, and G. A. Grell (2006), Satellite-observed U.S. power plant $\mathrm{NO}_{\mathrm{x}}$ emission reductions and their impact on air quality, Geophys. Res. Lett., 33, L22812, doi:10.1029/2006GL027749.

Lehman, J., et al. (2004), Spatio-temporal characterization of tropospheric ozone across the eastern United States, Atmos. Environ., 38, 4357-4369.

National Research Council (NRC) (2008), Estimating Mortality Risk Reduction and Economic Benefits from Controlling Ozone Air Pollution, 226 pp., Natl. Acad. Press, Washington, D. C.

Richter, A., et al. (2005), Increase in tropospheric nitrogen dioxide over China observed from space, Nature, 437, 129-132, doi:10.1038/ nature04092.

Ryan, W. F., et al. (1998), Pollutant transport during a regional $\mathrm{O}_{3}$ episode in the mid-Atlantic states, J. Air Waste Manage. Assoc., 48, 786-797.

Sillman, S. (1999), The relation between ozone, $\mathrm{NO}_{\mathrm{x}}$ and hydrocarbons in urban and polluted rural environments, Atmos. Environ., 33, 1821-1845.

Sillman, S., and P. J. Samson (1995), Impact of temperature on oxidant photochemistry in urban, polluted rural and remote environments, J. Geophys. Res., 100, 11,497-11,508.

West, J. J., et al. (2006), Global health benefits of mitigating ozone pollution with methane emission controls, Proc. Natl. Acad. Sci. U. S. A., 103, 3988-3993, doi:10.1073/pnas.0600201103.

Wilks, D. S. (2006), Statistical Methods in the Atmospheric Sciences, Int. Geophys. Ser., vol. 91, 2nd ed., Academic, Amsterdam.

Wu, S., L. J. Mickley, E. M. Leibensperger, D. J. Jacob, D. Rind, and D. G. Streets (2008), Effects of 2000-2050 global change on ozone air quality in the United States, J. Geophys. Res., 113, D06302, doi:10.1029/ 2007JD008917.

B. J. Bloomer, R. R. Dickerson, C. A. Piety, R. J. Salawitch, and J. W. Stehr, University of Maryland, 2403 Computer and Space Sciences Building, College Park, MD 20742, USA. (russ@atmos.umd.edu) 